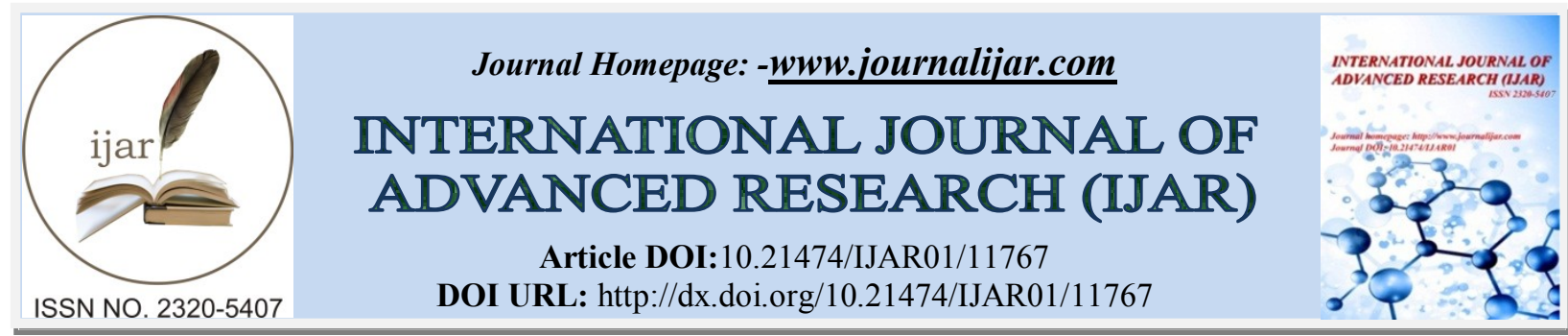

RESEARCH ARTICLE

\title{
EXPORT PERFORMANCE OF THREE MAJOR SECTORS AND A VIEW ON EXPORT CONCENTRATION: A STUDY ON BANGLADESH
}

MD Showgat Jahan Shourave

MA Economics (Final), Economics Department, Aligarh Muslim University.

\section{Manuscript Info}

Manuscript History

Received: 20 July 2020

Final Accepted: 24 August 2020

Published: September 2020

Key words:-

Export Performance,RMG, Jute,

Leather, Export Concentration,

Bangladesh

\section{Abstract}

Bangladesh's export earning has significantly increased over a period of time. Readymade garments (RMG), jute, and leather are the top three export earning sectors. This paper uses a multiple linear regression model to explain the relationship between total exports, and the top three export earning sectors. This paper finds Bangladesh's export performance is highly dependent on the RMG sector while Bangladesh has a comparative advantage for many other sectors in the global market. On the other hand, Bangladesh's export market is also concentrated with few countries. Less diversification in products and markets is a great concern for the export economy of Bangladesh because competition in the global export market is always rising. In such a situation there is no other way to emphasize product diversification and explore new markets to reduce high dependency on a few big markets.

Copy Right, IJAR, 2020,. All rights reserved.

\section{Introduction:-}

The export performance of a country influences its economic growth, employment, and the balance of payment situation. Several empirical studies (Feder 1982; Balassa 1978) using both time-series and cross-sectional data suggest that exports contribution to GDP growth more than just the exchange in the volume of exports. It must be mention that competition among exporters is also very high and several factors influence the export performance of a country like infrastructure, transportation, communication, regional and political integration, etc. Each country continuously modifying its export basket and destinations due to rising competition in the global market. However, to protect from this unwanted competition, every country tries to implement some pragmatic strategies like diversifying products and exploring new markets to hold a strong position in the world market.

Bangladesh is a developing country and has achieved consistent economic growth for the last ten years. Its export income has significantly increased over a period of time. There are several items in the export basket of Bangladesh which include traditional and non-traditional items like, readymade garments, leather and leather goods, agricultural products, jute and jute goods, IT, pharmaceutical and other chemical products, frozen food (fish and seafood), etc. Among all of these items, some are newly emerged and showing potential ability as a major contributor in the world market. Bangladesh is the top garment exporter in the world and has a relative advantage in the production of apparel items. The lion's share of export income comes from the readymade garments sector. The jute and leather sector occupied second and third position respectively in this list in terms of export earnings. 
According to Export Promotion Bureau (EPB) data, Bangladesh's export earnings grew by 10.55 percent in the financial year 2018-19. It is worth mentioning that despite having a double-digit export growth, it does not show a promising sustainable export growth in the long-run due to high dependency on a single sector. After RMG, jute and leather are the other two important sectors but their performance is not satisfactory. Their contribution is continuously reducing to the total export. Bangladesh failed to maintain export growth in these two sectors even when it had a higher revealed comparative advantage (RCA) in all items of raw jute, jute goods, and leather goods. Bangladesh is also suffering the problem of a narrow market for export products. Bangladesh exports mostly to the European Union (EU) countries and North America i.e. the United States and Canada while imports mostly from China, India, Singapore, Malaysia, and Indonesia. Bangladesh is underprivileged in terms of export earnings from her neighbouring countries.

This study aimed to find the relation between total export and the performance of three major export earning sectors along with an overview of the export concentration of Bangladesh. This paper is structured as follows; the next section presents a literature review followed by section 3 which presents details of the data and methodology. Section 4 present result and discussion. The last section is about the conclusion and policy recommendations of this study.

\section{A brief review of literature}

Bangladesh's export performance is related to larger commodity diversification of exports. A shift towards products in which Bangladesh has comparative advantage would presumably bring many gains from trade (Roy, 1991). He also added that demand for Bangladesh exports mostly from developed countries whereas demand from both developed and developing economy has a positive impact on Bangladesh exports.

Rahman (2008) in his paper "The Foreign Trade of Bangladesh: Its Composition, Performance, Trend, and Policy" found that Since the 1990s, the export sector of Bangladesh is performing well despite having some structural limitations. The export performance of primary commodities is comparatively poor that of manufactured commodities. He mentioned commodity and market concentration is a hindrance to Bangladesh's export economy. There is no other option than diversify exports and improve quality.

Ready-made garments have become the main export product of Bangladesh since the late 1980s. However, the RMG industry faces several challenges, for example, dependence on imported inputs, product and market concentration, labour compliance, lack of infrastructure, etc. (Ahmed, 2009). Demand for jute and jute products is rising in the world market because of world environmental issues. Bangladesh has a relative advantage in the production of jute and jute products. Technological up-gradation, skill development, diversified products can be a helpful measure to regain the past glory of jute (Rahman and Khaled, 2011). Similarly, Bangladeshi leather products have significant potentiality in international export (Islam and Siddique, 2014).

Bangladesh's export sector has registered commendable success in recent years but yet not able to utilize her full potentials. In many sectors, Bangladesh has a comparative advantage but till now the export basket remained undiversified. Bangladesh has failed successively to convert its comparative advantage into a competitive advantage (Hossain and Chowdhury, 2014). Besides, they comment that for developing countries geographic diversification is more important than product diversification.

Several studies have done on the export performance of Bangladesh. All of these studies have pointed out different key facts about export performance and contributed many implications or recommendations to facilitate this sector of the economy. However, the present paper attempts to analyze the export performance of three major sectors with keeping a view on the export concentration of Bangladesh.

\section{Data and Methodology:-}

This study uses the data of three major export earning sectors with total export income from a period of FY 1995-96 to FY 2019-20. These data are mainly collected fromthe Export Promotion Bureau (EPB), Bangladesh Bank, and Bangladesh Garment Manufacturers and Export Association (BGMEA).

In this study, I have come with a multiple linear regression model to predict total export earnings as an explained variable associated with RMG, jute, and leather exports as explanatory variables respectively. Besides, I calculated 
the log values of these four variables to transform into a more efficient model. The regression equation expressed as following:

$\ln T E_{i}=\beta_{1}+\beta_{2} \ln R M G_{i}+\beta_{3} \operatorname{lnJute}_{i}+\beta_{4} \operatorname{lnLeather~}_{i}+u_{i}$

Where,

$T E_{i}=$ Total export

$R M G_{i}=$ Export of ready-made garments

Jut $_{i}=$ Export of jute sector

Leather $_{i}=$ Export of leather sector

$\beta_{1}=$ Intercept for equation (1)

$\beta_{2}, \beta_{3}, \beta_{4}$ are the slope of RMG, jute, leather sector respectively and

$u_{i}=$ Error term for equation (1).

\section{Result and Discussion:-}

Multiple linear regression was calculated to predict total export earnings based on three important sectors which are $\mathrm{RMG}$, jute, and leather sector respectively. A significant regression equation was found $(F(3,21)=12129.26, p<$ $.000)$, with an $R^{2}$ of 0.99 . Table 1 and Table 2 provides the necessary information regarding this model.

Table 1:- OLS, using observations from 1995-96 to 2019-20 FY.

\begin{tabular}{|l|l|l|l|l|l|}
\hline & Coefficient & Std. Error & t-ratio & p-value & \\
\hline constant & 0.745639 & 0.0688374 & 10.83 & $<0.0001$ & $* * *$ \\
\hline RMG & 0.876919 & 0.0198850 & 44.10 & $<0.0001$ & $* * *$ \\
\hline Jute & 0.067859 & 0.0215405 & 3.150 & 0.0048 & $* * *$ \\
\hline Leather & 0.0361244 & 0.0292120 & 1.237 & 0.2299 & \\
\hline
\end{tabular}

\begin{tabular}{|l|l|l|l|l|}
\hline Mean dependent variable & 9.508706 & & S.D. dependent variable & 0.789534 \\
\hline Sum squared residual & 0.008629 & & S.E. of regression & 0.020271 \\
\hline R-squared & 0.999423 & & Adjusted R-squared & 0.999341 \\
\hline $\mathrm{F}(3,21)$ & 12129.26 & & P-value(F) & 0.000 \\
\hline
\end{tabular}

Note: Dependent variable; Total Export

Table 2:- Analysis of variance.

\begin{tabular}{|l|l|l|l|l|l|}
\hline & Sum of Squares & df & Mean Squares & F & Sig. \\
\hline Regression & 14.9521 & 3 & 4.984 & 12129.3 & 0.000 \\
\hline Residual & 0.008 & 21 & 0.0004 & & \\
\hline Total & 14.96 & 24 & 0.6233 & & \\
\hline
\end{tabular}

Source:Calculated by the author

Further, with the help of obtained values in the table (1), we can rewrite equation (1) as,

InT $E=0.745+0.876 \ln R M G_{i}+0.067$ lnJute $e_{i}+0.036$ ln Leather $_{i}$

From equation (2) we see that a 1 percent increase in the RMG export led on the average to about a 0.87 percent increase in the total export. Holding RMG and leather sector constant, a 1 percent increase in jute export led on the average to about a 0.067 percent increase in the total export. Similarly, holding the other two sectors constant, a percent increase in the leather sector led on the average to about 0.036 percent increase in the total export. From a statistical viewpoint, the estimated regression line fits the data quite well. The $R^{2}$ value of 0.99 means that 99 percent of the variation in the (log of) total export is explained by the logs of RMG, jute, and leather export.

\section{Ready-made garments}

Whenever we talk about the economy, growth, and export income of Bangladesh, it leads us to talk about the performance of the RMG sector. RMG sector plays a crucial role in the foreign exchange earnings of Bangladesh. Over the years Bangladesh's RMG industry has seen many positive changes. Nowadays, Bangladesh is considered as the top garments and textile exporter in the world. Especially, from FY 1995-96 to FY 2019-20, the RMG sector experienced a robust expansion in terms of export earnings and contribution to the total export. 
Figure 1:- RMG Export, Total Export, and Percentage Share of RMG Sector.

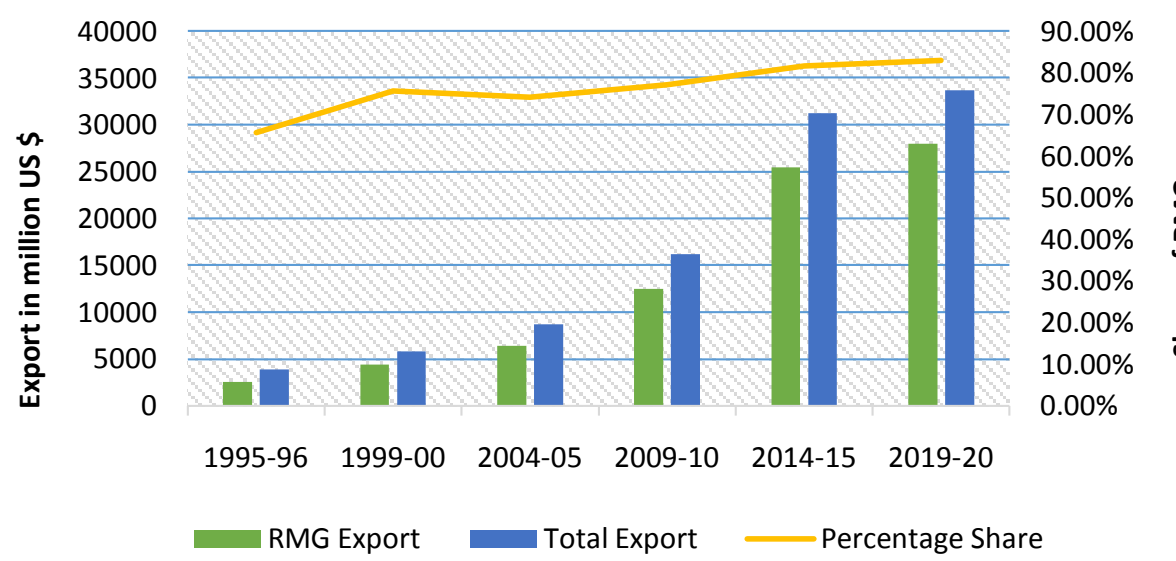

Source:- Export Promotion Bureau, Compiled by BGMEA.

In figure 1, we can graphically observe the relation between total export and RMG export. In the FY 1995-96, total RMG export was 2547.13 million US dollars which increased to 27949.19 million US dollars in FY 2019-20. Over the past years, the RMG sector contribution to the total export earnings has progressively increased. According to EPB, in FY 1995-96, the share of the RMG sector was 65.61 percent of total export and now it is 83 percent of the total export. Thus, it will not be wrong to say that RMG export is almost equal to the total export. Similarly, in the multiple linear regression model, I found that a 1 percent increase in the RMG export led on the average to about a 0 .87 percent increase in the total export which clearly shows the high dependency on the RMG sector. Thus, nobody can omit the significance of the RMG sector to total export earnings. With the passage of time, the number of garments factories has also increased. In FY 1984-85, the number of garment factories was 384 and now it stood at 4621 in 2018-19 as per BGMEA. A recent survey conducted by the Centre for Policy Dialogue (CPD), there are 3596 active RMG factories in Bangladesh where the number of workers approximately 3.5 million of which 60.8 percent are female and 39.2 percent are males. So, it has also a great impact on female employment along with social development.

Bangladesh exports a wide range of apparel products in a different region of the world. The market is often classified into traditional and non-traditional markets. The traditional markets simply refer largest export market while non-traditional markets refer to smaller export shares. Traditional markets include mainly the European Union (EU), USA, and Canada. According to EPB and BGMEA, the EU is the largest market for RMG export. In FY 2019-20, the total RMG export was 17146.18 million US dollars which were 61.35 percent of its total RMG export to the world while in the USA and Canada, it was 5146.53 million (18.41 percent) and 876.27 million (3.14 percent) respectively. France, Germany, Italy, Spain, and the UK are the largest importers of Bangladeshi RMG's from EU countries. Other than these three main destinations are considered as non-traditional markets. In FY 2019-20, Bangladesh earned 4780.20 million US dollars from non-traditional markets which were 17.1 percent of the total RMG export where Australia, Japan, China, Russia were the main buyers. Shirts, trousers, jackets, t-shirts, and sweaters are the five major products manufactured by the industry.

Bangladeshi readymade garments sector witnessed significant positive changes and as a result, it has brought pride to Bangladesh. It is also pointed out that the US-China trade war is an important factor for the sharp rise in RMG export in recent years. The Economist said, 'it is an issue as the global buyers shifted their orders from China to Bangladesh for having in alternative sourcing destination which made Bangladesh's position in the US market stronger than it was in the previous time'. Along with this fact, work plan safety, investment in the backward linkage industry, political stability, and duty-free access to the export destinations are considered as the vital factors for the sharp growth of the RMG sector.

\section{Jute and jute products}

When the whole world is concerned about global warming and environmental pollution, the demand for jute and jute products is increasing worldwide due to its eco-friendly nature. The production of jute and jute goods is also playing an important role in many developing economies. The production of jute is mainly concentrated in the south 
and south-east Asian regions. India has become the largest producer of jute due to its advanced production techniques along it is also the largest consumer of raw jute and jute products. As a result, India in a dominant position in the worldwide jute products market. However, Bangladesh is currently the second-largest producer of jute fiber and popular for its highest quality of jute fiber. Bangladesh's share is more than 70 percent, which makes Bangladesh the largest exporter of jute fiber in the world market. It must be mention that Bangladesh reached at this position due to its agro-climatic environment. The major exported jute products are hessian, sacking, and carpet backing cloth (CBC) which constitutes the major parts ofexport earnings of this sector. There is a huge demand for Bangladeshi jute and jute goods from all over the world and mainly this demand comes from Belgium, Canada, USA, UK, China, India, and Pakistan.

Jute is also known as the 'golden fiber' due to its golden brown colour and its contribution towards the Bangladeshi economy. It was the single dominant export item of Bangladesh till the 1980s. It will not be wrong to say that with the emergence of other manufacturing export-oriented products most likely, readymade garments products, leather goods, and footwear, it has lost its position in the national economy. It recently occupied the second position in the export basket of Bangladesh by crossing its closest competitor leather sector but still, its growth rate and share are incomparable against the RMG sector. From Table 3, we can observe the trends of export income earned by the jute sector. Further, we can see its modest increase in export but significantly reduced share of the total export. From FY 1995-96 to 2019-20, the export of jute items has increased to only 462.69 million US dollars but at the same time, its percentage share reduced from 10.81 percent to 2.62 percent.

Table 3:- Export of Jute Items and Its Share to Total Export (Values in million-dollar).

\begin{tabular}{|l|l|l|l|l|l|}
\hline FY & Jute Items & $\begin{array}{l}\text { Percentage } \\
\text { Share }\end{array}$ & FY & Jute Items & Percentage Share \\
\hline $1995-96$ & 419.66 & 10.81 & $2008-09$ & 417.42 & 2.68 \\
\hline $1996-97$ & 434.18 & 9.83 & $2009-10$ & 787.99 & 4.86 \\
\hline $1997-98$ & 389.19 & 7.54 & $2010-11$ & 1114.93 & 4.86 \\
\hline $1998-99$ & 375.6 & 7.07 & $2011-12$ & 967.38 & 3.98 \\
\hline $1999-00$ & 337.47 & 5.87 & $2012-13$ & 1030.61 & 3.81 \\
\hline $2000-01$ & 297.54 & 4.60 & $2013-14$ & 824.49 & 2.73 \\
\hline $2001-02$ & 304.66 & 5.09 & $2014-15$ & 868.53 & 2.78 \\
\hline $2002-03$ & 339.64 & 5.19 & $2015-16$ & 919.58 & 2.68 \\
\hline $2003-04$ & 326.15 & 4.29 & $2016-17$ & 962.4 & 2.78 \\
\hline $2004-05$ & 403.67 & 4.66 & $2017-18$ & 1025.53 & 2.79 \\
\hline $2005-06$ & 509.3 & 4.84 & $2018-19$ & 816 & 2.01 \\
\hline $2006-07$ & 467.93 & 3.84 & $2019-20$ & 882.35 & 2.62 \\
\hline $2007-08$ & 483.4 & 3.43 & & & \\
\hline S0urce & & & & \\
\hline
\end{tabular}

Source: Export Promotion Bureau (EPB), Bangladesh

A similar scenario has been observed in the proposed regression model, where we found that a 1 percent increase in jute export, led on the average to about 0.067 percent in the total export which is very negligible as compared to the RMG sector. This performance is embarrassing for the export sector economy especially when we present this sector as the second specialized sector.

As stated earlier that Bangladesh is the largest exporter of jute fiber and she earned fame for the production of highquality jute. However, the percentage share of jute export to the total export is declining day by day and the products are not diversified. Several reasons pointed out for this deteriorating condition. For example, the problem of land scarcity for cultivation, comparatively higher profitability from hybrid crops, high input cost, the disparity between the jute-rice price ratio, and the cultivation of jute in less productive lands are mainly responsible. As a result, the sector encounters lower productivity and low profit. According to a report of Bangladesh Jute research institute (BJRI) pricing policy, inadequate marketing support and lack of infrastructure had a significant negative impact on the production of jute and export earnings. The government should take initiatives to solve these problems to make a turnaround. 


\section{Leather and leather goods}

When we analyze the export performance of Bangladesh, it leads us to talk about the leather sector which occupied an important position after the RMG sector. High-value addition, private investment, and potential employment opportunities have brought this sector to this crucial position. Export composition of the leather sector is broadly classified into three categories of products: finished leather, leather goods, and footwear. However, it is worth to mention that the export of leather footwear dominates the export of total leather items. Key export destinations for these products are the EU, USA, Australia, Japan, Singapore, and South Korea.

According to the trade report of 2019-20, the leather sector placed the third position in terms of export earnings. Its export earnings were higher than the jute sector from 2013-14 to 2018-19 but recently has fallen behind the jute sector. According to the Export Promotion Bureau, in the fiscal year 2018-19, Bangladesh earned 1.01 billion US dollars exporting leather, leather goods, and leather footwear and crowned the only billion-dollar export earner after the apparel industry. However, in the recent three years, this sector witnessed negative growth. Export earnings from the leather industry continuously falling along with export share (see figure 3). In 2016-17, the percentage share was 3.54 which reduced to 2.36 percent in $2019-20$ as per EPB.

Figure 2:- Export of Leather and Leather Products.

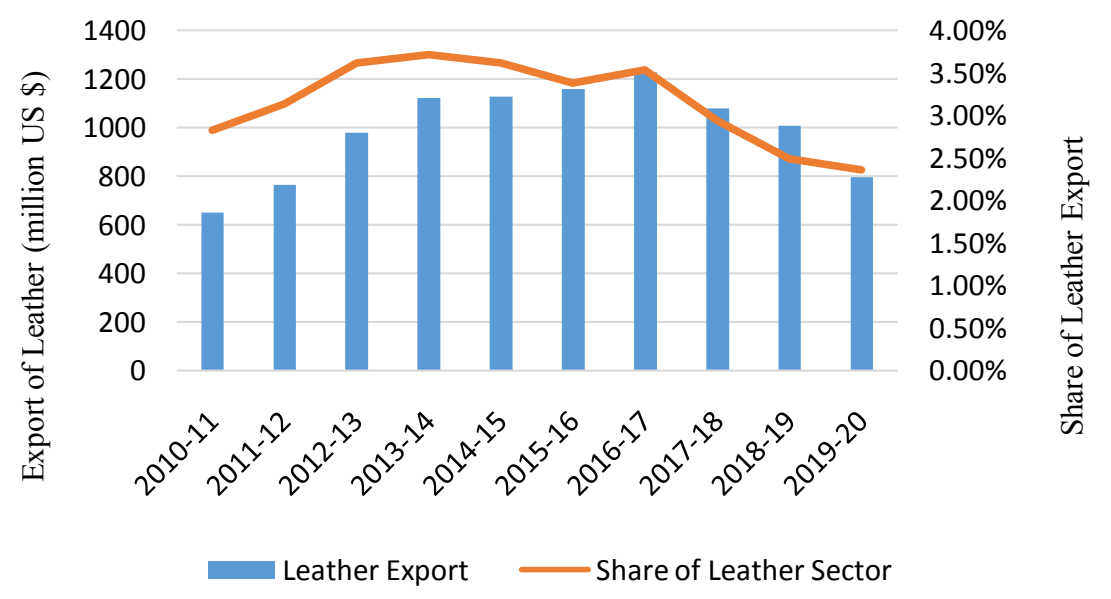

Source:- Export Promotion Bureau (EPB), Bangladesh.

From the multiple linear regression analysis we found that holding RMG and jute sector constant, 1 percent export increase led on the average to about 0.036 percent increase in the total export. So, we can say that like the jute sector, the total export dependency on the leather sector is also mere.

To ensure sustainable export performance for any sector, it is obligatory to diversify export products and explore new product destinations. Razzaque et al (2018) in their paper "Leather and leather goods export from Bangladesh: Performance, Prospects, and Policy Priorities" pointed out that Bangladesh exported the lowest number of products and her market is also concentrated. China, India, Vietnam are the main competitors. They export more leather items to a higher number of destinations and their export baskets are also significantly different from Bangladesh. Recently, the government of Bangladesh has forcibly moved tanneries from Hazaribagh to Savar to make the sector compliant and environment friendly. But construction of the new site yet to be completed especially, the central effluent treatment plant (CETP) at Savar Leather Industrial Park. Trade analysts and industry insiders considering this as a responsible event for the recent downward movement of the leather sector. The government of Bangladesh has set five billion US dollar export target of leather and leather goods by 2021 . However, the downtrend of this sector in recent years is a great concern for the economy.

\section{Concentration and diversification of export}

It is always said that export diversification plays a pivotal role for sustainable export performance. On the other hand, a high degree of export concentration is a great concern for the country's export economy. Export concentration occurs either in the form of a narrow range of goods and services or by the shrunk destination of products. 
As we know that the export of goods and services plays a crucial role in economic growth and development. However, when we look at undiversified products and markets of Bangladesh, it is disappointing for the economy as a whole. We saw the high dependency of total export on the RMG sector, whereas a negligible contribution of the jute and leather sector even occupied the second and third positions in the export basket. Figure 5 presents, export receipts of Bangladesh by the major commodities of three recent financial years. All commodities share reduced except RMG products. Any market fluctuations or unpredicted hit in this sector would highly affect the export sector economy of Bangladesh.

Figure 3:- Export Share of Some Selected Commodities (in percent).

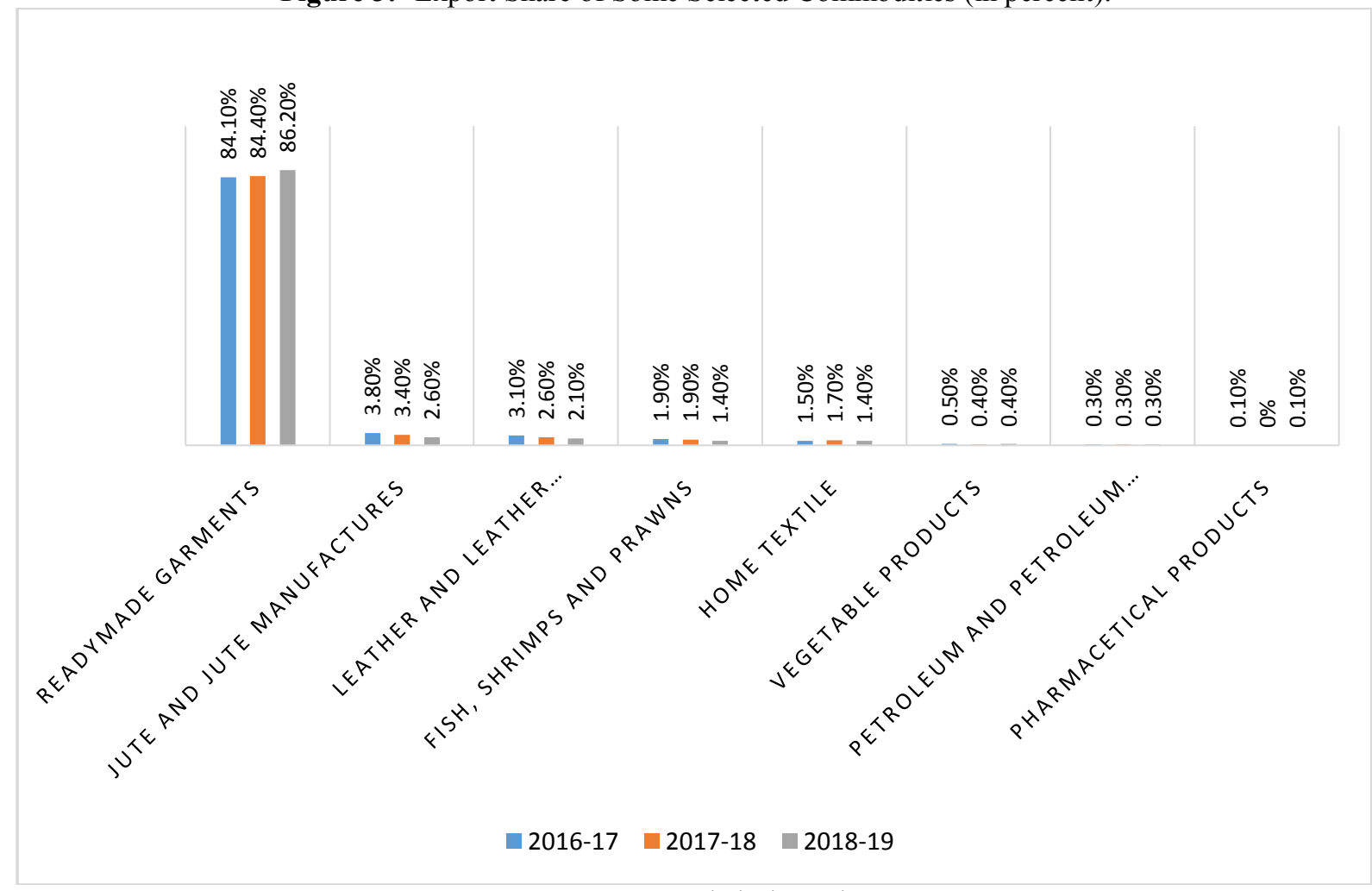

Source:- Bangladesh Bank.

Faiz and Maitra (2020) in their paper used the Herfindahl-Hirschman Index (HHI) method to show the degree of single sector domination on the export economy of some selected countries along with Bangladesh. In this method, there is only one dominant sector if the HHI $(100 \times 100)=10000$ and there would be two equal sectors if HHI is $(50 \times 50+50 \times 50)=5000$. It is found that Bangladesh's export depends on a single sector which is none other than the RMG sector. The contribution of other sectors is negligible. Figure 3 presents, Bangladesh's HHI increased over time which indicates that the dependency on a single sector has increased. 
Figure 4:- Bangladesh's HHI, 2009-2018.

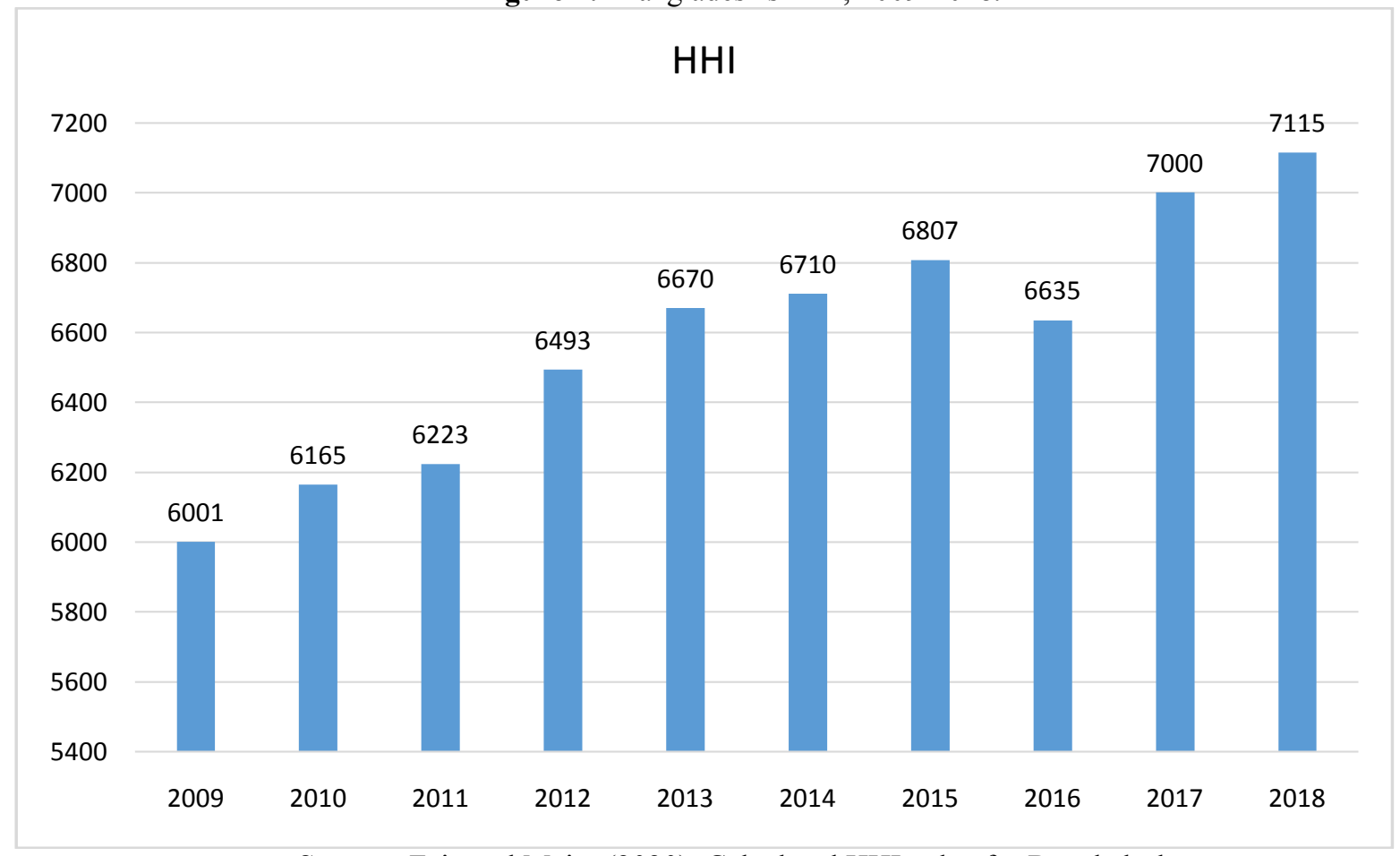

Source:-Faiz and Maitra(2020), Calculated HHI value for Bangladesh.

Similarly, when we talk about the export market, it is also limited in a way. According to Export Promotion Bureau data, in 2018-19 Bangladesh earned 4053.04 million US dollars of which 71.27 percent of the total export came from the USA, Germany, UK, Spain, France, Italy, Canada, Japan, Netherlands, and Poland. Among those USA, Germany, and the UK are the top three due to their large size of market and economy. The export share of these countries was $16.96,15.23$, and 10.29 percent respectively.

Bangladesh mostly imports from its neighbouring countries say China, India, Singapore, Malaysia, and Indonesia. But the export condition in these countries is appallingly poor. India and China are two big markets in the world economy. Over the past several decades, both country's trade has expanded at a breakneck pace. In 2018, China's total trade in goods was 12.4 percent of global trade even higher than the US (11.4 percent) and Germany (7.5 percent). For the same year, India's share in global exports for goods was 1.7 percent and in global imports was 2.6 percent. In FY 2018-19, Bangladesh's highest import was from China around 22 percent of the total imports, and second-highest from India approximately 13.1 percent. On the other hand, the share of total export in these two countries was only 2 percent and 3 percent respectively. The analysis of export statistics indicates Bangladesh's unusual trade deficit with China and India while other close competitors like Vietnam, Thailand, Indonesia, and Myanmar in a better position to export in China's market. Although, Bangladesh's export to China and India slowly increasing in recent years but still very low compared to its export to the western markets. 
Figure 5:- Country-Wise Export in 2018-19.

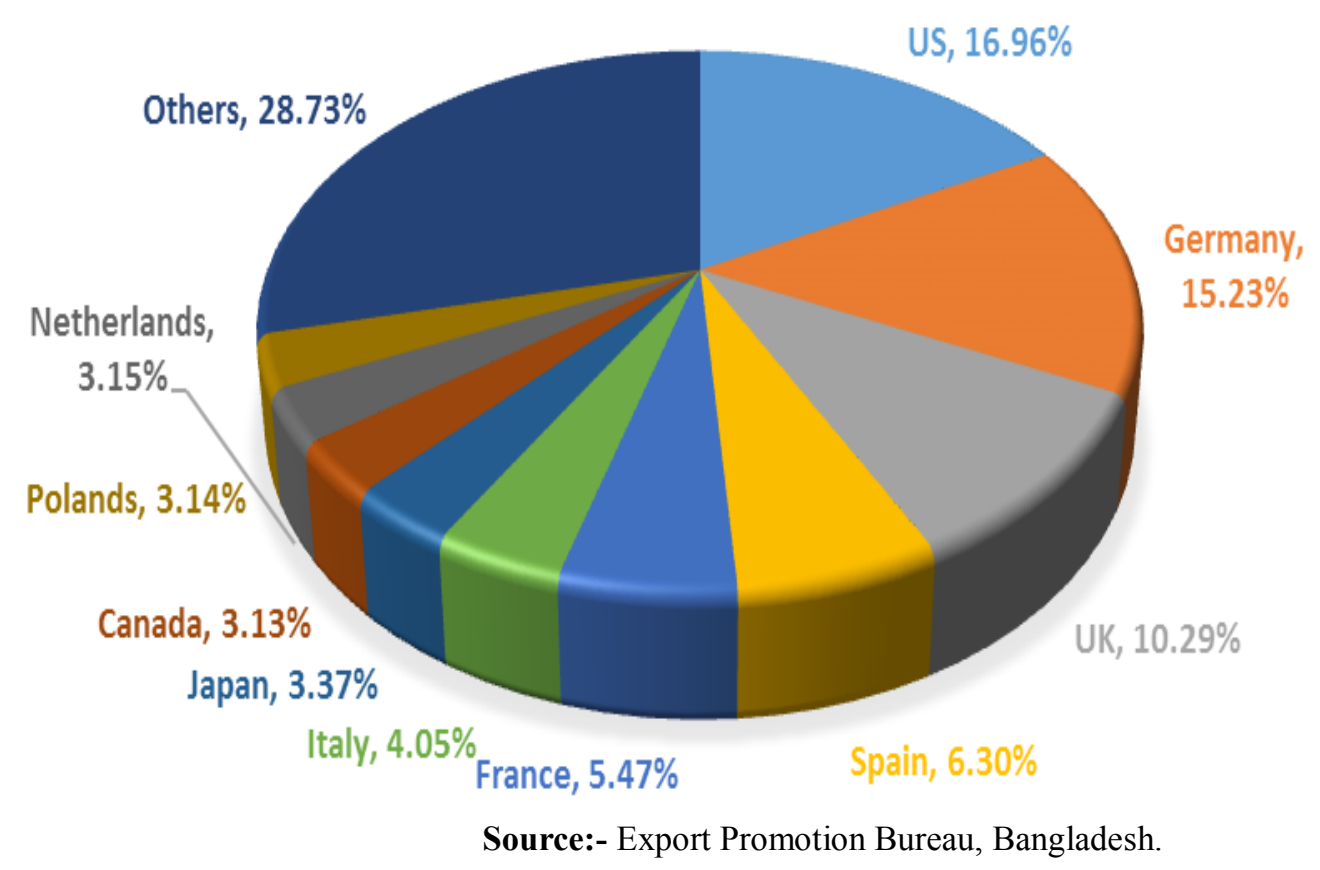

However, expansion of the market is mandatory for sustained export growth. High dependency on some big markets is highly risky and a great concern for the economy, because any unanticipated incident in these markets could adversely influence export earnings.

\section{Conclusion and Policy Recommendations:-}

With time, Bangladesh's export earning has increased significantly. In FY 2018-19 export growth was 10.55 percent as compared to the previous financial year but reduced in FY 2019-20 due to the crisis of pandemic. On the other side, we found its export earnings how much concentrated and dependent on a single sector. Export growth in other important sectors such as the jute and leather sector is stagnant.

Bangladesh's export market is also concentrated with few countries and rising competition in the export market is also a concern. In the meantime, main export competitors such as China, India, Thailand, and Vietnam are in a better position in terms of diversifying their products and markets. Vietnam has outdone Bangladesh to become the second-largest apparel exporter in the fiscal year 2019-20 which position was captured by Bangladesh for a long time.

In such a condition, it high time for Bangladesh to focus on product diversification as well as market diversification. Many studies revealed that for many products Bangladesh has a comparative advantage in the global market. Bangladesh should immediately give attention to promote these sectors by providing necessary supports to facilitate product diversification. In the meantime, exploring new markets will help to reduce dependency on a few big markets. Bangladesh needs to export more to neighbouring markets more specifically in China and India. The government should go for bilateral trade agreements to avail duty-free market access to new countries and that could be a solution for the problem of market concentration.

All in all, for the sake of sustained export growth and economic development, the government must have to ensure proper exchange rate protection policy, high foreign direct investment (FDI) inflows, friendly tariff regime, a good environment for trade, and most importantly pragmatic policy reformation.

\section{Acknowledgments:-}

This paper and the research behind it would not have been possible without the exceptional support of my supervisor, Dr. Mohammad Asif. His enthusiasm, knowledge, and exacting attention to detail have been an inspiration and kept my work on track. I am also grateful to Mr. Sajid-UR-Rahman for his kind support. 


\section{Disclosure statement}

I have no conflicts of interest to disclose.

\section{References:-}

1. Ahmed, N. (2009). Sustaining Ready-made Garment Exports from Bangladesh, Journal of Contemporary Asia, 39:4, 597-618, https://doi.org/10.1080/00472330903076891

2. Balassa, B. (1978). Exports and Economic Growth. Journal of Development Economics, pp.181-189.

3. Chowdhury, I. and Rashed, M. (2015). Market Access of Bangladesh's Jute in the Global Market: Present Status and Future Prospects. Journal of Economics and Sustainable Development, pp. 67-75, Vol.6, No.3.

4. Dornbusch, R., Fischer, D. and Samuelson, P. A. (1977). Comparative Advantage, Trade, and Payments in a Ricardian Model with a Continuum of Goods. American Economic Review, Vol. 67 No. 5, pp.823-839.

5. Economic Review (2018) Bangladesh Economic Review 2018, Dhaka: Ministry of Finance, Government of Bangladesh.

6. Environment (2011). International Jute Study Group (IJSG). Retrieved July 21, 2011. Available online at http://www.jute.org

7. EPB (various years) Bangladesh Export Statistics, different issues, Dhaka: Export Promotion Bureau of Bangladesh.

8. Fahim, A. (1998). Export Diversification and Growth: an empirical investigation. Applied Econometric Letters, 2000, Vol. 7, pp.559-562.

9. Faiz, M. and Maitra, P. (2020). Concentration and Diversification of Export Economy of Bangladesh: Comparison and Policy Implication with Other Asian Countries. South Asian Journal of Social Studies and Economics, 7(4): 19-36. https://doi.org/10.9734/SAJSSE/2020/v7i430197

10. Feder, G. (1982). On export and Economic Growth. Journal of Development Economics, 12.

11. Islam, S. and Siddique, P. J. (2014). Revealed Comparative Advantage of Bangladeshi Leather Industry with Selected Asian Economies. IOSR Journal of Business and Management, pp. 44-51. https://doi.org/10.9790/487X-161224451

12. Islam, S. (2001). The Textile and Clothing Industry of Bangladesh in a Changing World Economy, Dhaka: Centre for Policy Dialogue and the University Press Limited.

13. Ministry of Jute (2018). Bangladesh Jute Mills Corporation Report (BJMC)-2018. Dhaka.

14. Mlachila, M. and Yang, Y. (2004). The End of Textile Quotas: A Case Study of the Impact on Bangladesh. Washington DC: International Monetary Fund, IMF Working Paper, WP/04/108.

15. Rahman, M. M. (2008). The Foreign Trade of Bangladesh: It's Composition, Performance, Trend and Policy, pp. 25-36. Available at: http://www.academia.edu/4259548/The_Foreign_Trade_of_

16. Bangladesh_Its_Composition_Performance_Trend_and_Policy

17. Rahman, M. and Khaled, N. (2011). Global Market Opportunities in Export of Jute. CPD working Paper 93, Centre for Policy Dialogue (CPD).

18. Razzaque, A. (2005). Sustaining RMG Export Growth after MFA Phase-out: An Analysis of Relevant Issues with Reference to Trade and Human Development, Study conducted for Ministry of Commerce, Government of Bangladesh and United Nations Development Programme, mimeo.

19. Razzaque, A. M., Uddin, M., Rahman, J. (2018). Leather and Leather Goods Exports from Bangladesh: Performance, Prospects and Policy Priorities. A Study Prepared as part of the BEI project on Trade and Investment.

20. Roy, D. K. (1991). Determinants of Export Performance of Bangladesh. The Bangladesh Development Studies, Vol. XIX (4).

21. Roy, D. K. (1991). Determinants of Export Performance of Bangladesh: A Constant Market Share. The Bangladesh Development Studies, Vol. XIX (3).

22. Taslim, M. A. and Haque, M. S. (2011). Export Performance of Bangladesh. International Growth Centre, pp.1-47.

23. World Bank (2018) Bangladesh Development Update, Dhaka: The World Bank.

24. World Bank (2005) Bangladesh: Growth and Export Competitiveness, Dhaka: The World Bank.

25. World Trade Statistical review (2018), World Trade Organization. 